\title{
Maternal and Perinatal Outcome of Major Degree Placenta Previa at Mansoura University Hospital
}

\author{
SAMEH MASHALY, M.Sc.; EMAD FYALA, M.D.; ASHRAF GHANEM, M.D. and MOHAMAD NEZAR, M.D. \\ The Department of Obstetrics \& Gynecology, Faculty of Medicine, Mansoura University, Mansoura, Egypt
}

\begin{abstract}
Background: To study risk factors, management, and outcome of major degree placenta previa in our tertiary health care hospital.

Patients and Methods: A Prospective observational study was conducted in Obstetrics \& Gynecology, Department, Mansoura University Hospital, Egypt during the period from July, 2014 to December, 2015. The patient criteria, method of diagnosis, management, fetal and maternal outcomes of cases with major degree PP were reported and analyzed.

Results: This study included 115 cases. Mean age of our cases was 31.1 years (range: $21-40$ ), mean gestational age at delivery was 36.8 weeks (range: $28-39$ ). Previous cesarean deliveries were reported in $93.9 \%$ of the cases. Abnormal placental adhesions were found in $30.4 \%$. A stepwise system was used for intraoperative interference. Peripartum hysterectomy was performed in 13 cases $(11.3 \%)$. There were three cases of maternal mortality; one due to anesthetic complication, one due to uncontrolled atonic postpartum hemorrhage and the third was due to postoperative pneumonia. The mean gestational age at delivery was $36.82 \pm 1.6$ weeks. There were 5 cases $(4.3 \%)$ of IUFD and 2 cases $(1.8 \%)$ of early neonatal deaths.

Conclusions: Major placenta previa with accrete had significant difference in maternal morbidity and mortality than non-accrete type. Pathological placental adhesions should be excluded by Doppler ultrasound and or MRI. All surgical procedures to control bleeding must be done including hysterectomy without hesitation to save the patient. Cases must be managed by a collaborative team work in a tertiary center with available ICU.
\end{abstract}

Key Words: Maternal - Perinatal - Placenta previa.

\section{Introduction}

PLACENTA previa (PP) is defined as a placenta implanted in the lower uterine segment. It occurs in 2.8/1000 singleton pregnancies and 3.9/1000 twin pregnancies [1]. Ahmed and colleagues reported that the prevalence of placenta previa in Upper

Correspondence to: Dr. Emad Fyala, E-Mail: emadfyala@yahoo.com
Egypt was 13/1000 in 2015 [2]. Placenta previa represents a significant clinical problem, because the increased risk of antepartum, intrapartum, and postpartum hemorrhage as well as premature delivery. Furthermore, it was reported that the incidence of peripartum hysterectomy was $5.3 \%$ [3] Massive obstetrical hemorrhage in placenta previa is associated with severe maternal morbidity and mortality worldwide accounting for 30\% maternal deaths in Asia [4] . Perinatal mortality rates are three to four times higher than in normal pregnancies [1].

Placenta previa has been traditionally classified into lowlying, marginal, partial, or complete according to the degree to which the placenta encroaches upon the cervix during labor [5]

The association between prior CS, placenta previa, and pathological adherence of the placenta (PA) is well recognized. Nowadays, the incidence of placenta previa is rising because of the increasing $\mathrm{CS}$ rate $[6]$. Prenatal diagnosis of $\mathrm{PP}$ and $\mathrm{PA}$ is crucial in preparing for delivery. A number of imaging techniques, including ultrasound, color Doppler, and MRI are helpful in making a prenatal diagnosis of placenta accrete [7].

The management and outcome of PP depend mainly on the experience of the obstetrician and a well prepared hospital, so in this study we described the outcome of these cases in our tertiary health care hospital to put the positive and the negative points in our experience under supervision.

\section{Patients and Methods}

A Prospective observational study was conducted in Obstetrics \& Gynecology Department, Mansoura University Hospital, Egypt during the period from 1 st of July, 2014 to 31 st of December, 2015. 
This study included 115 pregnant women diagnosed by history and ultrasonography as major degree placenta previa (complete and incomplete centralis). After informed consent was obtained from all individual participants included in the study, the following data were recorded: Maternal age, parity, mode of previous deliveries, history of miscarriage or uterine surgery, and past history. Regarding current pregnancy; date of last menstrual period, gestational age at delivery, presenting complaint, and medical diseases associated with pregnancy. General and abdominal clinical examination was performed including obstetric grips. Routine Laboratory investigations were done including complete blood picture, blood sugar, Liver functions, serum creatinine, and coagulation profile. Prenatal imaging was performed including trans-abdominal ultrasound, color Doppler, and MRI.

After the diagnosis was confirmed as major degree placenta previa; the parents were counselled. The time of delivery was completed 37 weeks unless the patient presented earlier with emergency bleeding. Cesarean section was performed by a senior obstetrician after optimal preparation of the operating room. The operative details were recorded including type of surgery (elective or urgent), operative time, haemostatic sutures in placental bed, uterine artery ligation (UAL), internal iliac artery legation (IIAL), intrauterine balloon tamponade, cesarean hysterectomy, estimated intraoperative blood loss, Intra-operative blood transfusion, and surgical complications (e.g. bladder injury). Presence of pathologic placental adhesion (accreta, increta, and percreta) were also recorded.

The amount of intraoperative blood loss was estimated by sum of blood drained in the suction bottle and amount of absorbed blood in the towels as well as the difference between preoperative and postoperative hemoglobin and hematocrit values. Postoperative complications (postpartum hemorrhage, fever, wound sepsis), neonatal intensive care unit (NICU) admission, and maternal mortality.

Fetal outcome was recorded including maturity (Full term or preterm), Apgar score at 1 and 5 minutes, IUGR, congenital malformations, NICU admission, and early neonatal deaths.

\section{Statistical analysis:}

Data were analyzed with SPSS version 21 . The normality of data was first tested with one-sample Kolmogorov-Smirnovtest. Qualitative data were described using number and percent. Association between categorical variables was tested using Chi-square test. When $25 \%$ of the cells have ex- pected countless than5, Fisher exact test was used. Continuous variables were presented as mean \pm SD (standard deviation) for parametric data and Median for non-parametric data. The two groups were compared with Student $t$-test (parametric data) and Mann-Whitney test (nonparametric data). The difference was considered significant when $\mathrm{P}$ is less than or equal 0.05 .

\section{Results}

We reported 115 cases of major degree placenta previa. The criteria of our patients were reported in Table (1). As can be noticed from the table; mean age of our cases was 31.1 years (range: 21 40), the mean gestational age at delivery was 36.8 weeks (range: 28-39).

Table (1): Patients criteria.

\begin{tabular}{lcc}
\hline \multirow{2}{*}{ Items } & \multicolumn{2}{c}{ Study group $(\mathrm{n}=115)$} \\
\cline { 2 - 3 } & Mean $\pm \mathrm{SD}$ & Min-Max \\
\hline Age: & $31.12 \pm 4.33$ & $21-40$ \\
$<35 \mathrm{y}$ & 86 & 74.8 \\
$\geq 35 \mathrm{y}$ & 29 & 25.2 \\
Parity: & $2.35 \pm 1.1$ & $0-5$ \\
$\leq 2$ & 66 & 57.4 \\
$>2$ & 49 & 42.6 \\
Prev. C. $S:$ & $2.16 \pm 1.04$ & $0-5$ \\
0 & 7 & 6.1 \\
$0-2$ & 64 & 55.7 \\
$>2$ & 44 & 38.3 \\
G.A at $C$. S: & $36.82 \pm 1.6$ & $28-39$ \\
$<37 \mathrm{w}$ & 38 & 33 \\
$\geq 37 \mathrm{w}$ & 77 & 67 \\
Type of placenta: & & \\
Major anterior & 41 & 35.7 \\
Major posterior & 12 & 10.4 \\
Complete centralis & 62 & 53.9 \\
Cause of termination: & & \\
Elective & 80 & 69.6 \\
Emergent & 35 & 30.4 \\
\hline
\end{tabular}

During CS we adopted a stepwise system of intraoperative interference after fetal and placental delivery starting with hemostatic sutures in the placental bed (in 105 cases), followed by bilateral uterine artery ligation (in 92 cases), if bleeding was not controlled; we proceeded to bilateral internal iliac artery ligation (in 42 cases). Intrauterine balloon tamponade was used in 4 cases. Peripartum hysterectomy was performed in 13 cases $(11.3 \%)$. More data about operative interference are presented in Table (2). Moreover, there were three cases of maternal mortality; one of them was due to anesthetic complication, one due to uncontrolled atonic postpartum hemorrhage and the third was due to postoperative pneumonia. 
Table (2): Operative details and maternal outcome.

\begin{tabular}{|c|c|c|}
\hline \multirow{2}{*}{ Items } & \multicolumn{2}{|c|}{ Study group $(n=115)$} \\
\hline & No. & $\%$ \\
\hline \multicolumn{3}{|l|}{ Blood loss: } \\
\hline Median (Min-Max) & \multicolumn{2}{|c|}{$1800(300-7000)$} \\
\hline \multicolumn{3}{|l|}{ Blood transfusion: } \\
\hline Median (Min-Max) & \multicolumn{2}{|c|}{$3(0-12)$} \\
\hline \multicolumn{3}{|c|}{ Maneuvers to control bleeding: } \\
\hline \multicolumn{3}{|c|}{ Hemostatic sutures } \\
\hline \multicolumn{2}{|l|}{ Bilateral UAL* } & 80.0 \\
\hline Bilateral IIAL** & 42 & 36.5 \\
\hline Intrauterine balloon & 4 & 3.5 \\
\hline \multicolumn{3}{|l|}{ Maternal morbidity: } \\
\hline \multicolumn{3}{|l|}{ Bladder Injury } \\
\hline Hysterectomy & 13 & 11.3 \\
\hline \multicolumn{3}{|c|}{$\begin{array}{l}\text { Presence of abnormal placental } \\
\text { adhesion: }\end{array}$} \\
\hline \multicolumn{3}{|l|}{ Yes } \\
\hline No & 80 & 69.6 \\
\hline \multicolumn{3}{|l|}{ ICU admission: } \\
\hline \multicolumn{2}{|l|}{ Yes } & 19.1 \\
\hline No & 93 & 80.9 \\
\hline \multicolumn{3}{|l|}{ Maternal mortality: } \\
\hline \multicolumn{3}{|l|}{ Yes } \\
\hline No & 112 & 97.4 \\
\hline \multicolumn{3}{|c|}{ Postoperative hospital stay: } \\
\hline Median (Min-Max) & \multicolumn{2}{|c|}{$3(1-60)$} \\
\hline
\end{tabular}

$\mathrm{UAL}^{*}:$ Uterine artery ligation

IIAL **:Internal iliac artery ligation

The fetal outcome was summarized in Table (3). The mean gestational age at delivery was $36.82 \pm 1.6$ weeks. There were 5 cases $(4.3 \%)$ of IUFD and 2 cases $(1.8 \%)$ of early neonatal deaths.

There were statistically significant differences between patients with pathologic placental adherence (PA) and patients without PA regarding previous cesarean section and parity $(p<0.001)$, significant differences regarding age and type of placenta $(p<0.05)$ and non-significant differences regarding gestational age at cesarean section and cause of termination $(p>0.05)$. More differences were reported in Table (4).

Incidence of PA cases with major degree placenta previa in our study was 35 cases of all 115 patients $(30.4 \%)$. We did not report cases of placenta accrete in cases with no history of previous
$\mathrm{CS}$, in cases with history of previous $\leq 2 \mathrm{CS}$ is $7.8 \%$ and $68.2 \%$ in cases with history of previous $>2 \mathrm{CS}$ as can be seen in Table (5). Moreover, Table (6) demonstrates the differences of maternal and fetal outcomes in patients with and without pathological adhesions. There was a statistically significant difference between patients with PA and patients without PA regarding blood loss, blood transfusion, bilateral IUAL, bilateral IIAL, urinary tract injury, hysterectomy, ICU admission and postoperative hospital stay $(p<0.05)$.

Abnormal placental invasion was suspected by Doppler ultrasound in 45 of 115 cases and falsely diagnosed in 12 cases. Therefore, the sensitivity, specificity, positive predictive value, and negative predictive value were $94.3 \%, 85 \%, 73.3 \%$, and $97.1 \%$, respectively. PA was suspected on MRI in 24 of 41 cases and falsely diagnosed in one case. Therefore, the sensitivity, specificity, positive predictive value, and negative predictive value were $95.8 \%, 94.1 \%, 95.8 \%$, and95.1\%, respectively.

Table (3): Fetal outcome.

\begin{tabular}{|c|c|c|}
\hline \multirow{2}{*}{ Items } & \multicolumn{2}{|c|}{ Study group $(n=115)$} \\
\hline & No. & $\%$ \\
\hline \multicolumn{3}{|c|}{ NICU* admission: } \\
\hline Yes & 29 & 25.2 \\
\hline No & 86 & 74.8 \\
\hline \multicolumn{3}{|l|}{ IGUR: } \\
\hline Yes & 3 & 2.6 \\
\hline No & 112 & 97.4 \\
\hline \multicolumn{3}{|c|}{ Intrauterine fetal deaths: } \\
\hline Yes & 5 & 4.3 \\
\hline No & 110 & 95.7 \\
\hline \multicolumn{3}{|c|}{ Early neonatal deaths: } \\
\hline Yes & 2 & 1.8 \\
\hline No & 108 & 98.2 \\
\hline \multicolumn{3}{|c|}{ Fetal birth weight: } \\
\hline Mean \pm SD & \multicolumn{2}{|c|}{$2.63 \pm 0.43$} \\
\hline Min-Max & \multicolumn{2}{|c|}{$1.20-4$} \\
\hline \multicolumn{3}{|c|}{ APGAR score at 1 minutes: } \\
\hline Mean \pm SD & \multicolumn{2}{|c|}{$6.41 \pm 1.92$} \\
\hline Min-Max & \multicolumn{2}{|c|}{$0-10$} \\
\hline \multicolumn{3}{|l|}{ APGAR 5: } \\
\hline Mean \pm SD & \multicolumn{2}{|c|}{$8.74 \pm 1.62$} \\
\hline Min-Max & \multicolumn{2}{|c|}{$0-10$} \\
\hline
\end{tabular}

NICU*: Neonatal intensive care unit. 
Table (4): Comparison of criteria of patient having PP with and without abnormal placental adherence (PA).

\begin{tabular}{|c|c|c|c|c|c|}
\hline \multirow{2}{*}{ Items } & \multicolumn{2}{|c|}{ PA (maternal $n=35$ ) } & \multicolumn{2}{|c|}{ No PA $(n=80)$} & \multirow{2}{*}{$\begin{array}{c}\text { Test of sig. } \\
p \text {-value }\end{array}$} \\
\hline & No. & $\%$ & No. & $\%$ & \\
\hline $\begin{array}{l}\text { Age: } \\
<35 \mathrm{y} \\
\geq 35 \mathrm{y} \\
\text { Mean } \pm \mathrm{SD}\end{array}$ & $\begin{array}{l}22 \\
13\end{array}$ & $\begin{array}{l}62.9 \\
37.1 \\
7\end{array}$ & $\begin{array}{l}64 \\
16 \\
3(\end{array}$ & $\begin{array}{l}80.0 \\
20.0 \\
.18\end{array}$ & $\begin{array}{l}\mathrm{X}^{2}=3.79 \\
p=.051 \\
t=3.28, p=.001 *\end{array}$ \\
\hline $\begin{array}{l}\text { Parity: } \\
\quad \leq 2 \\
\quad>2 \\
\text { Median (Min-Max) }\end{array}$ & $\begin{array}{l}5 \\
30\end{array}$ & $\begin{array}{l}14.3 \\
85.7\end{array}$ & $\begin{array}{l}61 \\
19\end{array}$ & $\begin{array}{l}76.2 \\
23.8 \\
-\end{array}$ & $\begin{array}{l}\mathrm{X}^{2}=38.23 \\
p=\leq .001^{* *} \\
\mathrm{Z}=5.92, p=\leq .001 * *\end{array}$ \\
\hline $\begin{array}{l}\text { Prev. C. S: } \\
\quad 0 \\
\leq 2 \\
>2 \\
\text { Mean } \pm \mathrm{SD}\end{array}$ & $\begin{array}{l}0 \\
5 \\
30\end{array}$ & $\begin{array}{l}0 \\
14.3 \\
85.7\end{array}$ & $\begin{array}{l}7 \\
59 \\
14\end{array}$ & $\begin{array}{l}8.8 \\
73.8 \\
17.5 \\
\end{array}$ & $\begin{array}{l}\mathrm{X}^{2}=48.14 \\
p=\leq .001 * * \\
\mathrm{Z}=6.54, p=\leq .001 * *\end{array}$ \\
\hline $\begin{array}{l}\text { G.A at C.S } \\
\quad<37 \mathrm{w} \\
\geq 37 \mathrm{w} \\
\text { Mean } \pm \mathrm{SD}\end{array}$ & $\begin{array}{r}25 \\
10 \\
3\end{array}$ & $\begin{array}{l}71.4 \\
28.6 \\
.95\end{array}$ & $\begin{array}{r}13 \\
67 \\
3\end{array}$ & $\begin{array}{l}16.3 \\
83.7 \\
.42\end{array}$ & $\begin{array}{l}\mathrm{X}^{2}=1.67 \\
p=.196 \\
t=.874, p=.384\end{array}$ \\
\hline $\begin{array}{l}\text { Type of placenta: } \\
\text { Major anterior } \\
\text { Major posterior } \\
\text { Complete centralis }\end{array}$ & $\begin{array}{l}8 \\
0 \\
27\end{array}$ & $\begin{array}{l}22.9 \\
0 \\
77.1\end{array}$ & $\begin{array}{l}25 \\
20 \\
35\end{array}$ & $\begin{array}{l}31.2 \\
25.0 \\
43.8\end{array}$ & $\begin{array}{l}\mathrm{X}^{2}=12.27 \\
p=.002 *\end{array}$ \\
\hline $\begin{array}{l}\text { Cause of termination: } \\
\text { Elective } \\
\text { Emergent }\end{array}$ & $\begin{array}{l}27 \\
8\end{array}$ & $\begin{array}{l}77.1 \\
22.9\end{array}$ & $\begin{array}{l}53 \\
27\end{array}$ & $\begin{array}{l}66.2 \\
33.8\end{array}$ & $\begin{array}{l}\mathrm{X}^{2}=1.36 \\
p=.243\end{array}$ \\
\hline
\end{tabular}

Table (5): Incidence of placenta accrete in relation to number of previous CS.

\begin{tabular}{|c|c|c|c|c|c|c|c|c|}
\hline & \multicolumn{2}{|c|}{$\begin{array}{c}\text { No previous CS } \\
(\mathrm{n}=7)\end{array}$} & \multicolumn{2}{|c|}{$\begin{array}{c}\text { Previous } \leq 2 \text { CS } \\
(n=64)\end{array}$} & \multicolumn{2}{|c|}{$\begin{array}{c}\text { Previous }>2 \text { CS } \\
(n=44) \\
\end{array}$} & \multicolumn{2}{|c|}{$\begin{array}{l}\text { Total } \\
(115)\end{array}$} \\
\hline & No. & $\%$ & No. & $\%$ & No. & $\%$ & No. & $\%$ \\
\hline Placenta accrete & 0 & 0 & 5 & 7.8 & 30 & 68.2 & 35 & 30.4 \\
\hline No placenta accrete & 7 & 8.8 & 59 & 92.2 & 14 & 31.8 & 80 & 69.6 \\
\hline
\end{tabular}

Table (6): Comparison of maternal outcome in women having PP with and without PA.

\begin{tabular}{|c|c|c|c|c|c|}
\hline \multirow{2}{*}{ Items } & \multicolumn{2}{|c|}{ PA $(n=35)$} & \multicolumn{2}{|c|}{ No PA $(n=80)$} & \multirow{2}{*}{$\begin{array}{l}\text { Test of sig. } \\
p \text {-value }\end{array}$} \\
\hline & No. & $\%$ & No. & $\%$ & \\
\hline $\begin{array}{l}\text { Blood loss: } \\
\text { Median (Min-Max) }\end{array}$ & \multicolumn{2}{|c|}{$3000(900-7000)$} & \multicolumn{2}{|c|}{$1200(300-3000)$} & $\mathrm{Z}=5.51, p=\leq .001^{* *}$ \\
\hline $\begin{array}{l}\text { Blood transfusion: } \\
\text { Median (Min-Max) }\end{array}$ & \multicolumn{2}{|c|}{$4(1-12)$} & \multicolumn{2}{|c|}{$2(0-6)$} & $\mathrm{Z}=5.76, p=\leq .001 * *$ \\
\hline $\begin{array}{l}\text { Maneuvers to control } \\
\text { bleeding: } \\
\text { Hemostatic sutures } \\
\text { Bilateral UAL } \\
\text { Bilateral IIAL } \\
\text { Intrauterine Ballon }\end{array}$ & $\begin{array}{l}33 \\
33 \\
28 \\
3\end{array}$ & $\begin{array}{l}94.3 \\
94.3 \\
80.0 \\
8.6\end{array}$ & $\begin{array}{l}72 \\
59 \\
14 \\
1\end{array}$ & $\begin{array}{l}90 \\
73.8 \\
17.5 \\
1.2\end{array}$ & $\begin{array}{l}\mathrm{X}_{2}^{2}=.563, p=.453 \\
\mathrm{X}_{2}=6.41, p=.011^{*} \\
\mathrm{X}^{2}=41.02, p=\leq .001^{* *} \\
\text { Fisher's Exact, } p=.083\end{array}$ \\
\hline $\begin{array}{l}\text { Maternal morbidity: } \\
\text { UT-injury } \\
\text { Hysterectomy }\end{array}$ & $\begin{array}{l}11 \\
13\end{array}$ & $\begin{array}{l}31.4 \\
37.1\end{array}$ & $\begin{array}{l}1 \\
0\end{array}$ & $\begin{array}{l}1.2 \\
0\end{array}$ & $\begin{array}{l}\mathrm{X}_{2}^{2}=23.72, p=\leq .001 * * \\
\mathrm{X}^{2}=33.50, p=\leq .001 * *\end{array}$ \\
\hline $\begin{array}{l}\text { ICU admission: } \\
\text { Yes } \\
\text { No }\end{array}$ & $\begin{array}{l}14 \\
21\end{array}$ & $\begin{array}{l}40.0 \\
60.0\end{array}$ & $\begin{array}{l}8 \\
72\end{array}$ & $\begin{array}{l}10.0 \\
90.0\end{array}$ & $\begin{array}{l}\mathrm{X}^{2}=14.16 \\
p=\leq .001 * *\end{array}$ \\
\hline $\begin{array}{l}\text { Maternal mortality: } \\
\text { Yes } \\
\text { No }\end{array}$ & $\begin{array}{l}3 \\
32\end{array}$ & $\begin{array}{l}8.6 \\
91.4\end{array}$ & $\begin{array}{l}0 \\
80\end{array}$ & $\begin{array}{l}0 \\
100\end{array}$ & $\begin{array}{l}\text { Fisher's } \\
\text { Exact, } p=.027^{*}\end{array}$ \\
\hline $\begin{array}{l}\text { Postop. Hosp. Stay: } \\
\text { Median (Min-Max) }\end{array}$ & & & & & $\mathrm{Z}=6.183, p=\leq .001^{* *}$ \\
\hline
\end{tabular}




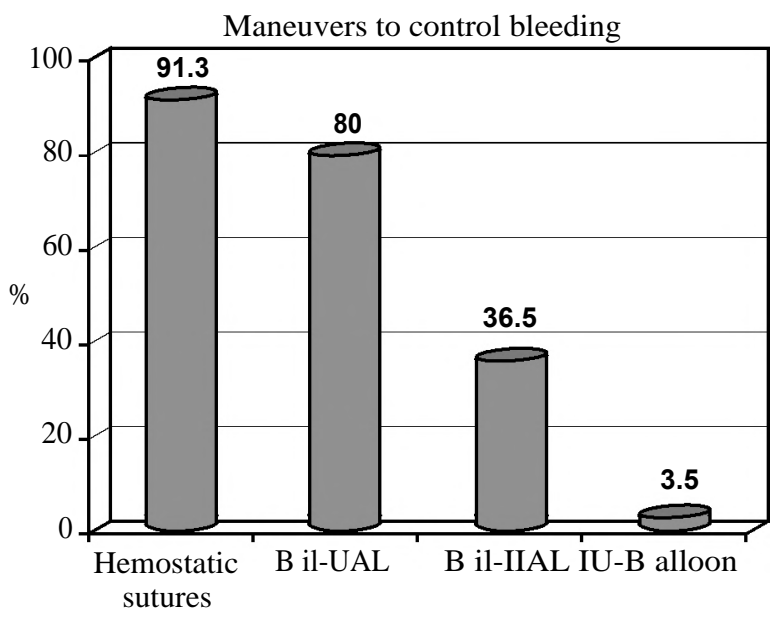

Fig. (1)

Bil-UAL: Bilateral uterine artery ligation. Bil-IIAL: Bilateral internal iliac artery ligation. IU-Balloon: Intrauterine balloon.

\section{Discussion}

Maternal and fetal morbidity and mortality from PP are considerable, and associated with high demands on health care resources. Given the rising incidence of cesarean section combined with increasing maternal age, the number of cases of PP and its complications, including PA, will continue to increase [8]. It is important to identify women who may be at increased risk for closer monitoring during their pregnancies. The prevalence, management, and outcome of major degree placenta previa vary from center to another. We conducted this prospective study to investigate this health problem in our tertiary health care center which is a referral center of high risk Obstetric cases in Delta region, Egypt (about 12 million populations).

We recruited 115 eligible women. The mean age was $31.12 \pm 4.33$ years which agreed with Wang et al., [9] who reported that PP occurred more in older women (between 30 and 40 years) compared to pregnancies without $\mathrm{PP}$.

Incidence of PA incases with major degree placenta previa in our study was 35 of 115 patients (30.4\%), occurrence of placenta accrete incases with previous $>2 \mathrm{CS}$ was $68.2 \%$ compared to zero $\%$ in cases with no history of previous CS $(p \leq 0.001)$, this suggests a strong association.Our findings agreed with other authors [5]. Cesarean sections interfere with normal physiological stretching of the lower segment in subsequent pregnancies, thus preventing normal migration of the placenta away to the upper uterine segment and this resulted in increased incidence of placenta previa [10]

Regarding control of post partum bleeding at cesarean section; we used a stepwise approach which has been previously published by colleagues in our center [11] included haemostatic uterine sutures in placental bed in 105 cases (91.3\%), bilateral uterine artery ligation in 92 cases (80\%), bilateral internal iliac artery ligation in 42 cases (36.5\%) and intrauterine balloon (Foley's catheter) in 4 cases (3.5\%). Cho et al., [12] used haemostatic suturing technique in 23 women with postpartum hemorrhage at cesarean who didn't respond to conservative treatment. In all cases, bleeding decreased markedly and hysterectomy was avoided. Refaie et al., [13] performed bilateral internal iliac artery ligation before placental delivery in patients with invasive placenta (accrete and increta) in 46 of 51 cases $(90.1 \%)$ and satisfactory hemostasis was achieved in 38 patients $(82.6 \%)$. In five patients with placenta previa increta $(29.4 \%)$, they proceeded to cesarean hysterectomy due to uncontrolled blood loss.

In our study we used inflated balloon of Foley`s catheter in 3 cases as Bakri balloon is not available in our center. In the study of Cho et al., [14]; sixtyfour patients $(46.7 \%)$ required uterine balloon tamponade during cesarean section due to postpartum bleeding from the lower uterine segment, of whom $50(78.1 \%)$ had placenta previa centralis. The overall success rate was $75 \%$ for placenta previa patients.

Bladder is the most frequently involved organ in placenta percreta [15]. Surgical injuries are due to the invasion of the bladder in placenta percreta together with multiple adhesions as a result of repeated cesarean sections. In our study, urinary tract injury occurred in 12 cases $(10.4 \%)$ all were bladder injuries and no cases were complicated by bowel injury in comparison with $13.2 \%$ bladder and $3.8 \%$ bowel injuries in study conducted by Ahmed et al., in 2015 [2]. In meta-analysis of 54 cases of placenta percreta, bladder injury was reported as high as $26 \%$ [16]

Regarding fetal outcome; PP is known to be associated with prematurity. However, there is debate about the effect of PP on fetal growth; some studies have suggested that pregnancies with PP are at risk of low birth weight and a low Apgar score. Some authors $[\mathbf{1 7 , 1 8}]$ have shown high neonatal morbidity associated with PP. On the other hand, [19] we did not observe adverse neonatal effects in such cases. In another recent study from Egypt [2], prematurity was reported in $13.5 \%$ of cases, there were $13.2 \%$ fresh still born babies, and $17 \%$ admission to NICU. In comparison to our study prematurity (gestational age $<37$ weeks) was $33 \%$ we had $4.3 \%$ still born babies and $25.2 \%$ 
admission to NICU. This difference may be due to higher number of emergent CS before 37 weeks gestation in our study reaching 35 cases $(30.4 \%)$.

In a cohort study consisted of $3,550,842$ deliveries comparing neonatal outcomes born to mothers with placenta previa beyond 37 weeks gestation to those delivered to other indications, authors found that placenta previa was an independent risk factor for adverse neonatal outcomes [20]. The reasons behind the effect of placenta previa on fetal growth remains matter of much debate among scientists, some argue that placenta previa is not an independent risk factor for impaired fetal growth and no significant difference in birth weight in neonates born to mothers with placenta previa and those delivered to normal placenta locations [21].

Although ultrasound is the main stay in the imaging of PA, MRI has been used as adjunct in diagnosis when ultrasound results were equivocal. In our study, the sensitivity, specificity, positive predictive value, and negative predictive value of Doppler ultrasound to diagnose abnormal placental invasion were $94.3 \%, 85 \%, 73.3 \%$, and $97.1 \%$, respectively. PA was suspected on MRI in 24 of 41 cases and falsely diagnosed in one case. Therefore, the sensitivity, specificity, positive predictive value, and negative predictive value were $95.8 \%$, $94.1 \%, 95.8 \%$, and $95.1 \%$, respectively. These results agreed with D'Antonio et al., [22] who reported sensitivity of $90.7 \%$ for US and $94.4 \%$ for MRI; and specificity of $96.9 \%$ for US and $84 \%$ for MRI. It also agreed with Meng et al., [23] who showed that ultrasound sensitivity was $83 \%$ and its specificity was $95 \%$ compared with $82 \%$ and $88 \%$ respectively for MRI.

There were 3 cases $(2.6 \%)$ of maternal mortalities; one of them was due to anesthetic complications, one due to uncontrolled atonic postpartum hemorrhage and the third was due to postoperative pneumonia. However, other authors [2,24] reported no cases of maternal mortalities. This different outcome may be due to different facilities and resources.

\section{Conclusion:}

The most significant risk factors for placenta previa were previous cesarean section, smoking, high parity, previous D\&C, previous miscarriages, and anemia. Cases must be managed in a tertiary center with available ICU. Pathological placental adhesions should be excluded by Doppler ultrasound and MRI. All surgical procedures to control bleeding must be done including hysterectomy without hesitation to save the patient.

\section{Author contribution:}

Mashaly S. Collection of data.

Fyalah E. Operative interference.

Ghanem A. and Nizar M. Supervision of the work and statistical analysis.

\section{Compliance with ethical standards:}

Conflict of interest: The authors declare no conflict of interest with contents of the manuscript.

\section{Funding: No research funding was provided.}

Ethical approval: The research was approved by the Institutional Research Board of Faculty of Medicine, Mansoura University, Egypt (IRB no $\mathrm{R} / 16.08 .65)$.

\section{References}

1- ANANTH C.V., DEMISSIE K., SMULIAN J.C. and VINTZILEOS A.M.: Placenta previa in singleton and twin births in the United States, 1989 through 1998: A comparison of risk factor profiles and associated conditions. Am. J. Obstet. Gyecol., 188 (1): 275-281, 2003.

2- AHMED S.R., AITALLAH A., ABDELGHAFAR H.M. and ALSAMMANI M.A.: Major placenta previa: Rate, maternal and neonatal outcomes experience at a Tetrtiary Maternity Hospital, Sohag, Egypt: A prospective study. J. Clin. Diagn. Res., 9 (11): QC17-19, 2015.

3- CRANE J.M., VANDENHOF M.C., DODDS L., ARMSON B.A. and LISTON R.: Maternal complications with placenta previa. Am. J. Perinatol., 17 (2): 101-105, 2000.

4- KAINER F. and HASBARGEN U.: Emergencies associated with pregnancy and delivery: Peripartum haemorrhage. Dtsch Arztebl Int., Sep., 105 (37): 629-38, 2008.

5- YAZDANI T., ISLAM A., NADEEM G., HAYAT T. and MUSHTAQ M.: Frequency of abnormal placentation in patients with previous caesarean section. J. Rawalpindi Med. Coll., 11 (1): 39-41, 2007.

6- GILLIAM M. and ROSENBERG DAND DAVIS F.: The likelihood of placenta previa with greater number of cesarean deliveries and higher parity. Obstet. Gynecol., 99 (6): 976-980, 2002.

7- YANG J.I., LIM Y.K., KIM H.S., CHANG K.H., LEE J.P. and RYU H.S.: Sonographic findings of placental lacunae and the prediction of adherent placenta in women with placenta previa totalis and prior cesarean section. Ultrasound Obstet. Gyneco., 128 (2): 178-182, 2006.

8- WU S., KOCHERGINSKY M. and HIBBARD J.U.: Abnormal placentation: Twenty-year analysis. Am. J. Obstet. Gynecol., 192 (5): 1458-61, 2005.

9- YANG Q., WEN S.W., OPPENHEIMER L., CHEN X.K., BLACK D., GAO J. and WALKER M.C.: Association of caesarean delivery for first birth with placenta praevia and placental abruption in second pregnancy. BJOG, 114 (5): 609-613, 2007

10- HERSHKOWITZ R., FRASER D. and MAZOR MANDLEIBERMAN J.R.: One or multiple previous cesarean sections are associated with similar increased frequency 
of placenta previa. Eur. J. Obstet. Gynecol. Reprod Biol., 62 (2): 185-188, 1995.

11-SHABANA A., FAWZY M. and REFAIE W.: Conservative management of placenta percreta: A stepwise approach. Arch. Gynecol. Obstet., 291 (5): 993-8, 2015.

12- CHO J.H., JUN H.S. and LEE C.N.: Hemostatic suturing technique for uterine bleeding during cesarean delivery. Obstet. Gynecol., 196 (1): 129-131, 2000.

13-REFAIE W., FAWZY M. and SHABANA A.: Prophylactic bilateral internal iliac artery ligation for management of low-lying placenta accreta: A prospective study. Tanta Med. J., 42 (4): 146-150, 2014.

14- CHO H.Y., PARK Y.W., KIM Y.H., JUNG I. and KWON J.Y.: Efficacy of intrauterine bakri balloon tamponade in cesarean section for placenta previa patients. PLo SOne, 10 (8): e0134282, 2015.

15- CALISKAN E., TAN O., KURTARAN V., DILBAZ B. and HABERAL A.: Placenta previa percreta with urinary bladder and ureter invasion. Arch. Gynecol. Obstet., 268 (4): 343-344, 2003.

16- WASHECKA R. and BEHLING A.: Urologic complications of placenta percreta invading the urinary bladder: A case report and review of the literature. Hawaii Med. J., 61 (4): 66-69, 2002.

17- NORGAARD L.N., PINBORG A., LIDEGAARD O. and BERGHOLT T.: A Danish national cohort study on neonatal outcome in singleton pregnancies with placenta previa. Acta. Obstet. Gynecol. Scand, 91 (5): 546-551, 2012.
18- BALAYA J. and BONDARENKO H.D.: Placenta accreta and the risk of adverse maternal and neonatal outcomes. J. Perinat. Med., 41 (2): 141-149, 2013.

19- ROSENBERG T., G. PARIENTE, R. SERGIENKO, A WIZNITZERAND and E. SHEINER: Critical analysis of risk factors and outcome of placenta previa. Arch. Gynecol. Obstet., 284 (1): 47-51, 2011.

20- SCHNEIDERMAN M. and BALAYLA J.: A comparative study of neonatal outcomes in placenta previa versus cesarean for other indication at term. J. Matern. Fetal Neonatal Med., 26 (11): 1121-1127, 2013.

21- YENIEL A.O., ERGENOGLU A.M., UTIL I.M., ASKAR N. and MESERI R.: Effect of placenta previa on fetal growth restriction and stillbirth. Arch. Gynecol. Obstet., 286 (2): 295-298, 2012.

22- D'ANTONIO F., IACOVELLA C., PALACIOSJARAQUEMADA J., BRUNO C.H., MANZOLI L. and BHIDE A.: Prenatal identification of invasive placentation using magnetic resonance imaging: Systematic review and meta-analysis. Ultrasound Obstet. Gynecol. Jul., 44 (1): 8-16, 2014.

23- MENG X., XIE L. and SONG W.: Comparing the diagnostic value of ultrasound and magnetic resonance imaging for placenta accreta: A systematic review and metaanalysis. Ultrasound Med. Biol., 39 (11): 1958-1965, 2013.

24- KHASHOGGI T.: Maternal and neonatal outcome in major placenta previa. Ann. Saudi Med. Jul., 15 (4): 313 6, 1995.

\section{نتائج حالات المشيمة المتقدمة العظمى للأم والجنين

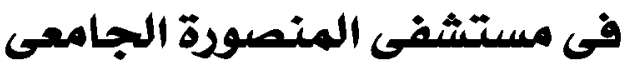

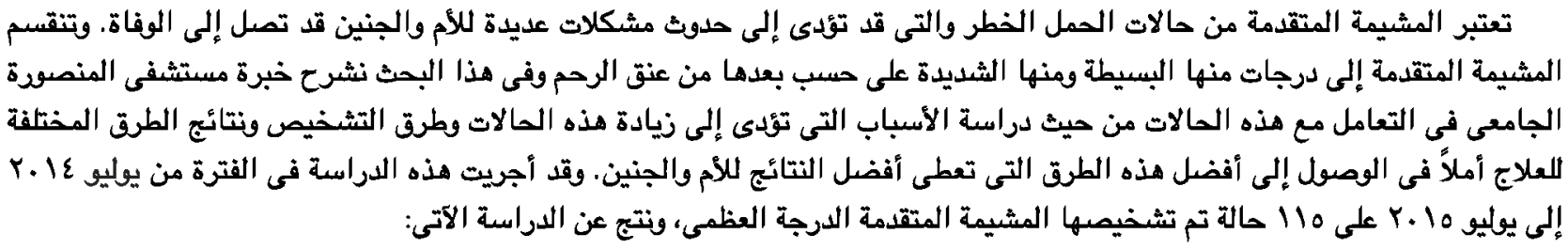

من أهم أسباب زيادة هذه الحالات في الولادة القيصرية السابقة لوجود ألتصاق مرضى بالمشيمة من أهم العوامل التى تؤدى إلى مشاكل

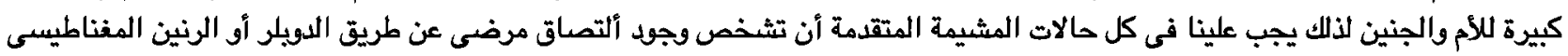

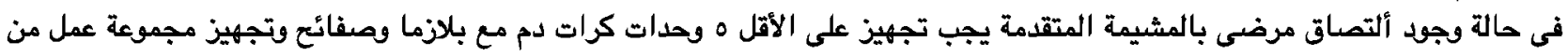

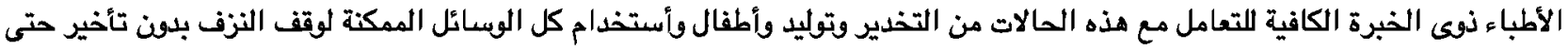

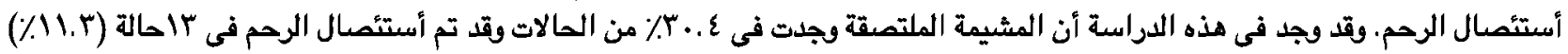

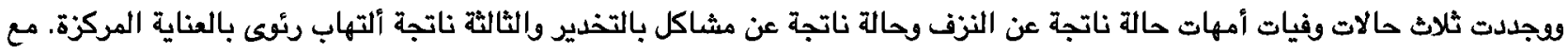

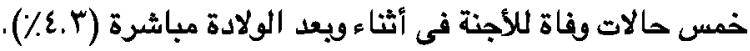

